\title{
RELATIONSHIPS WITHIN BALSAMINOID ERICALES: A WOOD ANATOMICAL APPROACH ${ }^{1}$
}

\author{
Frederic Lens, ${ }^{2,5}$ Stefan Dressler, ${ }^{3}$ SteVen JANSEN, $, 2,4$ \\ LIESBETH VAN EVELGHEM, ${ }^{2}$ AND ERIK SMETS ${ }^{2}$
}

\begin{abstract}
${ }^{2}$ Laboratory of Plant Systematics, Institute of Botany and Microbiology, K.U.Leuven, Kasteelpark Arenberg 31, B-3001 Leuven, Belgium; ${ }^{3}$ Forschungsinstitut Senckenberg, Senckenberganlage 25, D-60235 Frankfurt/M., Germany; and ${ }^{4}$ Jodrell Laboratory, Royal Botanic Gardens, Kew, Richmond, Surrey, TW9 3DS UK
\end{abstract}

\begin{abstract}
Wood samples of 49 specimens representing 31 species and 11 genera of woody balsaminoids, i.e., Balsaminaceae, Marcgraviaceae, Pellicieraceae, and Tetrameristaceae, were investigated using light microscopy and scanning electron microscopy. The wood structure of Marcgraviaceae, Pellicieraceae, and Tetrameristaceae is characterized by radial vessel multiples with simple perforation plates, alternate vessel pitting, apotracheal and paratracheal parenchyma, septate libriform fibers, and the presence of raphides in ray cells. Tetrameristaceae and Pellicieraceae are found to be closely related based on the occurrence of unilaterally compound vessel-ray pitting and multiseriate rays with long uniseriate ends. The narrow rays in Pelliciera are characteristic of this genus, but a broader concept of Tetrameristaceae including Pelliciera is favored. Within Marcgraviaceae, wide rays (more than five-seriate) are typical of the genus Marcgravia. Furthermore, there is evidence that the impact of altitude and habit plays an important role in the wood structure of this family. The wood structure of Balsaminaceae cannot be compared systematically with other balsaminoids because of their secondary woodiness. Balsaminaceae wood strongly differs due to the presence of exclusively upright ray cells in Impatiens niamniamensis, the absence of rays in Impatiens arguta, and the occurrence of several additional paedomorphic features in both species.
\end{abstract}

Key words: Balsaminaceae; balsaminoid clade; Ericales; Marcgraviaceae; paedomorphism; Pellicieraceae; Tetrameristaceae; wood anatomy.

The balsaminoid clade of Ericales comprises Balsaminaceae, Marcgraviaceae, Pellicieraceae, and Tetrameristaceae (Anderberg et al., 2002; Bremer et al., 2002). These families include a total number of 12 genera and about 1130 species, depending on the number of species accepted within Impatiens L. (more than 900 and still increasing according to Yuan et al., 2004; about 1000 according to Fischer, 2004). Balsaminaceae, which include the monotypic Hydrocera Blume and the huge genus Impatiens, are predominantly herbaceous and often grow in montane areas of the tropics and subtropics of the Old World. Only a few Impatiens species have a stem with a woody base, while the three other families are all woody. The neotropical Marcgraviaceae, comprising seven genera and about 130 species, include many lianas but also climbing shrubs and some trees (Dressler, 2004). The mangrove tree Pelliciera rhizophorae Planch. \& Triana, the only representative of Pellicieraceae, grows in tidal swamps along the Pacific coast from Costa Rica to Ecuador (Kobuski, 1951) and more sparsely on the Atlantic coast of Nicaragua, Panama, and Colombia (Roth and Grijalva, 1991). The two genera of Tetrameristaceae have a peculiar distribution pattern: Tetramerista

\footnotetext{
${ }^{1}$ Manuscript received 23 July 2004; revision accepted 8 February 2005. The authors thank the directors of the Botanic Garden and Botanic Museum Berlin-Dahlem (B), National Botanic Garden of Belgium (BR), Forschungsinstitut Senckenberg (FR), Missouri Botanical Garden (MO), New York Botanical Garden (NY), Swedish Museum of National History (S), the directors of the xylaria of Madison (MADw), Tervuren (Tw), Utrecht (Uw), and Washington (USw), and Dr. Yuan (University of Neufchâtel, Switzerland) for their supply of wood samples. We also thank Anja Vandeperre (K.U.Leuven) for technical assistance and Marcel Verhaegen (National Botanic Garden of Belgium) for preparing SEM images. This work has financially been supported by research grants from the K.U.Leuven (OT/01/25) and the Fund for Scientific Research-Flanders (Belgium) (G.0104.01, 1.5.069.02, 1.5.061.03, G.0268.04). Steven Jansen was a postdoctoral fellow of the Fund for Scientific Research-Flanders (Belgium) (F.W.O.-Vlaanderen).

${ }^{5}$ Author for correspondence (e-mail: frederic.lens@bio.kuleuven.ac.be)
}

Miq. is represented by large trees growing in tropical Southeast Asia, while the monotypic Pentamerista Maguire is a shrub or small tree occurring in the Guayana Highlands of Venezuela (Maguire et al., 1972).

The balsaminoid clade, which is sister to all other ericalean families, is one of the few groups in Ericales that is well supported based on molecular sequence data (Savolainen et al., 2000; Soltis et al., 2000; Anderberg et al., 2002; Bremer et al., 2002; Geuten et al., 2004). Marcgraviaceae, Pellicieraceae, and Tetrameristaceae were considered to be closely related by most earlier botanists, and Hallier $(1916,1921)$ even placed them in one family. On the other hand, the inclusion of Balsaminaceae is surprising because of the aberrant systematic position of this family in previous morphological classifications (Cronquist, 1988; Dahlgren, 1989; Takhtajan, 1997; Thorne, 2000). Furthermore, interfamily relationships within the balsaminoid clade remain obscure. It is clear that Pelliciera is closely related to Tetrameristaceae, and should possibly be merged in Tetrameristaceae sensu lato (s.l.) (Bremer et al., 2002; APG II, 2003), but the question of whether this family is more related to Marcgraviaceae than to Balsaminaceae is still a matter of dispute. Anderberg et al. (2002) suggest that Balsaminaceae take the most basal position with Marcgraviaceae sister to Pellicieraceae and Tetrameristaceae, while in the analyses of Bremer et al. (2002) Marcgraviaceae turn out to be the most basal family with Balsaminaceae sister to Tetrameristaceae s.l. In addition, the balsaminoid clade according to Geuten et al. (2004) is divided into two sister clades, a Balsaminaceae-Marcgraviaceae clade and a Pellicieraceae-Tetrameristaceae clade.

Intrafamily relationships of Balsaminaceae and Marcgraviaceae are far from being resolved. Within Impatiens, the delimitation of species groups is very difficult due to hybridization processes (Grey-Wilson, 1980). Molecular analyses of ITS sequence data revealed some interesting new relationships 
within Impatiens, although the basal groups remain poorly understood (Yuan et al., 2004). Within Marcgraviaceae, variation in inflorescences and differences in the shape and position of nectary bracts resulted in three new genera that were recently elevated from the Norantea Aubl. s.l. complex, i.e., Marcgraviastrum (Wittm. ex Szyszyl.) de Roon \& S. Dressler, Sarcopera Bedell, and Schwartzia Vell. (de Roon and Dressler, 1997). Phylogenetic analyses based on chloroplast sequences supported two subfamilies, Marcgravioideae (including Marcgravia L.) and Noranteoideae (including all other genera), but relationships within Noranteoideae were poorly resolved (Ward and Price, 2002).

The wood structure of the balsaminoid clade has received only little attention. Wood samples of Pelliciera were studied by Record (1942) and Baretta-Kuipers (1976), and Tetrameristaceae were investigated by Maguire et al. (1972). A wood anatomical comparison of Tetrameristaceae, Pellicieraceae, and Marcgraviaceae was made by Bedell (1980) in her unpublished master's thesis. Consequently, the secondary xylem of Marcgraviaceae is poorly known, and only a few studies deal with some representatives of this family, such as Juel (1887), Beauvisage (1920), Williams (1936), Vestal (1937), Record and Hess (1943), Metcalfe and Chalk (1950), de Roon (1975), and Dressler (1994). Furthermore, as far as we know, only one paper described very briefly the wood structure of an Impatiens species (Gerard, 1917).

This study provides detailed wood anatomical descriptions of the poorly known families Balsaminaceae and Marcgraviaceae, which are compared with additional observations of Pellicieraceae and Tetrameristaceae. Wood anatomical variation in Marcgraviaceae will be used to test intrafamily relationships and to determine to what extent differences in habit and altitude may influence the secondary xylem. Within the predominantly herbaceous Balsaminaceae, the possibility of secondary woodiness of two Impatiens species is investigated. The wood anatomical variation observed will be used to comment on the difficult interfamily relationships within the balsaminoid clade.

\section{MATERIALS AND METHODS}

Wood samples of 49 specimens representing 31 species and 11 genera were investigated using LM and SEM. Transverse and longitudinal sections of approximately $25 \mu \mathrm{m}$ were cut using a sledge microtome (Reichert, Vienna, Austria). After bleaching, the sections were stained with a mixture of safranin and alcian blue $(35: 65)$, dehydrated in an ethanol series $(50,75,96 \%)$ and mounted in Euparal (Agar Scientific, Stansted, UK). Macerations were prepared according to Franklin (1945). Sections were observed using a Dialux 20 light microscope (Leitz, Wetzlar, Germany) and photographed with a DP50-CU digital camera (Olympus, Hamburg, Germany). Wood sections for SEM observations were gold-coated with a sputter coater (SPI Supplies, West Chester, Pennsylvania, USA), and observed using a JEOL JSM-5800 LV scanning electron microscope (JEOL, Tokyo, Japan).

The wood anatomical terminology follows the "IAWA list of microscopic features for hardwood identification" (IAWA Committee, 1989). In order to investigate the impact of altitude and habit on the wood of Marcgraviaceae, four groups were made. These four groups include 16 climbing lowland specimens (growing under $1000 \mathrm{~m}$ ), four climbing montane species (occurring above $1000 \mathrm{~m}$ ), two erect species from the lowlands, and three erect species from the montane regions. Only species with mature wood were taken into account. In general, a stem diameter of $15 \mathrm{~mm}$ or more was considered to include mature wood, except for the mature wood specimen Marcgravia pedunculosa Triana \& Planch. (Uw 4837, $12 \mathrm{~mm}$ ). In addition, the wood specimen of Marcgravia brownei (Triana \& Planch.) Krug \& Urb. (FR, 15 mm) was considered to be juvenile because of the large amount of pith parenchyma tissue. The species used in the four categories are indicated in Table 2. Statistical differences were calculated at the $0.5 \%$ level using the software program Statistics Calculator version 8.0. (StatPac Inc., Bloomington, Indiana, USA).

In Pellicieraceae and Tetrameristaceae, libriform fibers are obviously present, but in Marcgraviaceae it is sometimes difficult to distinguish between fiber-tracheids and libriform fibers because many intermediate fiber types occur according to the definitions of Baas (1986a) and Carlquist (2001). Therefore, we prefer to give a detailed description of these fibers. For all quantitative data on fibers, 25 measurements based on clearly identifiable cells in maceration slides were taken into account.

The wood samples studied are listed in Table 1 with reference to the origin, collector, and the diameter of the wood sample in millimeters.

\section{RESULTS}

The material studied is described according to family. For each genus examined, the numerator gives the number of species studied and the denominator includes the total number of species. Numbers between brackets are extreme values. Values for vessel multiples, pits, bar number, axial parenchyma cells per strand, ray width, and ray density are maximum ranges. A summary of the results is presented in Table 2.

Balsaminaceae (Impatiens 2/ca. 1000; Figs. 1-7)-Growth ring boundaries absent. Wood diffuse-porous. Vessels (10)$30-50-(64) / \mathrm{mm}^{2}$, usually solitary (Figs. $1-2$ ), occasionally in radial multiples of 2-3, vessel outline angular. Vessel perforation plates generally simple (Fig. 5), but very few scalariform perforations with 1-3 bars in I. arguta Hook. f. \& Thoms. Lateral wall pitting mostly scalariform or sometimes reticulate (Figs. 6-7), minutely bordered, pit cavities 10-75 $\mu \mathrm{m}$ in horizontal size, non-vestured. Tangential diameter of vessels (25)-40-80-(100) $\mu \mathrm{m}$, vessel elements (130)-210300-(450) $\mu \mathrm{m}$ long; vessels storied in I. niamniamensis Gilg; thin-walled tyloses abundant in vessels of I. niamniamensis (Figs. 2, 4). Tracheids absent. Fibers non-septate, thin-walled, and relatively wide, (360)-570-640-(900) $\mu \mathrm{m}$ long, with mostly simple to occasionally minutely bordered pits equally distributed in radial and tangential walls, pits $1-3 \mu \mathrm{m}$ in diameter, fibers occasionally storied in both species. Axial parenchyma scanty paratracheal in I. arguta (Fig. 1), 3-7 cells per strand; abundant in I. niamniamensis (Fig. 2), vasicentric or in bands of 2-3 cells wide, sometimes up to 5 cells, 1-2 cells per strand. Rays absent in tiny stem of I. arguta (Fig. 3), but exclusively multiseriate in I. niamniamensis, ray cells storied (Fig. 4), 11-21 cells wide (Figs. 2, 4), more than 7000 $\mu \mathrm{m}$ high, $1-2$ rays/mm, consisting of upright cells only; sheath cells absent; very small simple pits between ray cells, usually $2 \mu \mathrm{m}$ in horizontal size. Rare occurrence of raphides in tyloses of I. niamniamensis.

Marcgraviaceae (Marcgravia 13/60, Marcgraviastrum 2/ 15, Norantea 2/2, Ruyschia Jacq. 2/7, Sarcopera 1/10, Schwartzia 4/14, Souroubea Aubl. 3/19; Figs. 8-20)Growth ring boundaries usually indistinct by changes in fiber diameter and wall thickness, growth rings sometimes absent. Wood diffuse-porous. Vessels (2)-4-90-(100)/ $/ \mathrm{mm}^{2}$, solitary or in radial multiples of mostly $2-4$, sometimes up to seven vessels, vessel outline rounded (Figs. 8-10). Vessel perforation plates predominantly simple in mature wood (Fig. 14), scalariform perforations with 1-11 bars common in metaxylem and sporadic in mature wood (Fig. 15). Intervessel pits alternate, 
TABLE 1. Species list with reference to the family, origin, collector, and the diameter of the wood sample in millimeters. "Mature" means that the wood sample is derived from mature wood with an estimated diameter of at least $30 \mathrm{~mm}$ based on the divergence of the rays, although the exact diameter could not be traced. Institutional wood collections and herbaria used in this study are abbreviated according to the Index Xylariorum (Stern, 1988) and Index Herbariorum (Holmgren et al., 1990). Authors of plant names are abbreviated according to Brummitt and Powell (1992).

\begin{tabular}{l}
\hline \hline \multicolumn{1}{c}{ Species studied } \\
\hline Impatiens arguta Hook. f. \& Thoms. \\
I. niamniamensis Gilg \\
Marcgravia brachysepala Urb. \\
M. brownei (Triana \& Planch.) Krug \& Urb. \\
M. brownei (Triana \& Planch.) Krug \& Urb. \\
M. coriacea Vahl
\end{tabular}

M. coriacea Vahl

M. evenia Krug \& Urb. subsp. evenia

M. evenia Krug \& Urb. subsp. calcicola (Britton) S. Dressler

M. oligandra Griseb.

M. pendunculosa Triana \& Planch.

M. pendunculosa Triana \& Planch.

M. pendunculosa Triana \& Planch.

M. purpurea I.W. Bailey

$M$. rectiflora Triana \& Planch.

M. schippii Standl.

M. sintenisii Urb.

M. sintenisii Urb.

$M$. sp.

M. stonei Utley

M. tobagensis Urb.

M. umbellata $\mathrm{L}$.

M. umbellata $\mathrm{L}$.

M. umbellata $\mathrm{L}$.

Marcgraviastrum mixtum (Triana \& Planch.) Bedell M. subsessile (Benth.) Bedell

Norantea goyasensis Cambess.

N. guianensis Aubl.

N. guianensis Aubl. subsp. japurensis (Mart.) Bedell

N. guianensis Aubl. subsp. japurensis (Mart.) Bedell Pelliciera rhizophorae Planch. \& Triana

Pelliciera rhizophorae Planch. \& Triana

Pentamerista neotropica Maguire

Pentamerista neotropica Maguire

Ruyschia sp.

$R$. tremadena (Ernst) Lundell

Sarcopera tepuiensis (de Roon) Bedell subsp. coccinea de Roon \& S. Dressler

S. tepuiensis (de Roon) Bedell subsp. tepuiensis

Schwartzia adamantium (Cambess.) Gir.-Cañas

S. costaricensis (Gilg) Bedell

S. diaz-piedrahitae Gir--Cañas

S. spiciflora (A.L. Juss.) Bedell

Souroubea guianensis Aubl. subsp. cylindrica

(Wittm.) de Roon

S. guianensis Aubl. subsp. guianensis

S. sp.

$S$. sp.

S. sympetala Gilg

S. sympetala Gilg

Tetramerista glabra Miq.

Tetramerista glabra Miq.

Family

Balsaminaceae

Balsaminaceae

Marcgraviaceae

Marcgraviaceae

Marcgraviaceae

Marcgraviaceae

Marcgraviaceae

Marcgraviaceae

Marcgraviaceae

Marcgraviaceae

Marcgraviaceae

Marcgraviaceae

Marcgraviaceae

Marcgraviaceae

Marcgraviaceae

Marcgraviaceae

Marcgraviaceae

Marcgraviaceae

Marcgraviaceae

Marcgraviaceae

Marcgraviaceae

Marcgraviaceae

Marcgraviaceae

Marcgraviaceae

Marcgraviaceae

Marcgraviaceae

Marcgraviaceae

Marcgraviaceae

Marcgraviaceae

Pellicieraceae

Pellicieraceae

Tetrameristaceae

Tetrameristaceae

Marcgraviaceae

Marcgraviaceae

Marcgraviaceae

Marcgraviaceae Marcgraviaceae

Marcgraviaceae

Marcgraviaceae

Marcgraviaceae

Marcgraviaceae

Marcgraviaceae Marcgraviaceae Marcgraviaceae Marcgraviaceae Marcgraviaceae Tetrameristaceae Tetrameristaceae

\begin{tabular}{l}
\multicolumn{1}{c}{ Origin } \\
China \\
tropical Africa \\
Jamaica \\
Venezuela \\
Nicaragua \\
Guyana \\
Cuba \\
Cuba \\
Cuba \\
Surinam \\
Surinam \\
Surinam \\
Surinam \\
Puerto Rico \\
Panama
\end{tabular}

Puerto Rico

Puerto Rico

Surinam

Mexico

Tobago

Dominica

Dominica

Saba

Colombia

Panama

Brazil

Surinam

Venezuela

Brazil

Colombia

Panama

Venezuela

Venezuela

Colombia

Venezuela

Venezuela

Guyana

Brazil

Panama

Colombia

Dominica

Venezuela

Surinam

unknown

Panama

Venezuela

Panama

Borneo

Malaysia

Collector

Y.-M. Yuan and X.-J. Ge 2003-57

unknown (BR)

Thorne and Proctor 48220 (NY)

F. J. Breteler 3246 (Uw 10998)

S. Dressler and G. Zizka 325 (FR)

M. A. Reinders and A. Thom 135 (Uw 34636)

Flora Cuba Project 52315 (B)

S. Dressler s.n. (B)

Diameter

Flora Cuba Project 49159 (B)

$2 \mathrm{~mm}$

$6 \mathrm{~mm}$

$10 \mathrm{~mm}$

$58 \mathrm{~mm}$

$15 \mathrm{~mm}$

$34 \mathrm{~mm}$

R. S. Cowan and J. C. Lindeman $39177 \quad 12 \mathrm{~mm}$ (Uw 4837)

Land-, Bos- en Bouwbeheer 15302 (Uw 15 mm 21928)

J. C. Lindeman 4177 (Uw 3107)

J. C. Lindeman et al. 448 (Uw 21819)

P. Sintenis 4461 (MO)

R. Mangelsdorff and G. Zizka RMP $18 \mathrm{~mm}$ 1316 (FR)

P. Sintenis 5321 (BR)

B. Boom 6893 (NY)

Schulz 7750 (Uw 5090)

S. Dressler s.n. 17.3.2004 (FR)

R. S. Cowan $1420(\mathrm{~S})$

K. L. Chambers 2518 (Uw 15399)

W. H. Hodge 1048 (USw)

I. Boldingh 2275B (U)

A. E. Lawrence 504 (Tw 34691)

R. Mangelsdorff and G. Zizka RMP 1313 (FR)

B. Maguire et al. 56587 (Uw 16440)

G. Stahel 2998 (Tw 31227)

$6 \mathrm{~mm}$

$11 \mathrm{~mm}$

J. J. Wurdack and L. S. Adderley 43256 (USw 17934)

B. A. Krukoff 8915 (BR)

J. Cuatrecasas 19999 (Tw 39723, MADw 17595)

S. Dressler s.n. 26.2.2004 (FR)

B. Maguire et al. 42865 (Tw 36842)

J. J. Wurdack and L. S. Adderley 42865 (MADw 23508)

J. van Rooden et al. 402 (Uw 25576) $32 \mathrm{~mm}$

L. Williams 10021 (Uw 35102) $24 \mathrm{~mm}$

B. Maguire and L. Politi 28537 (Tw $43 \mathrm{~mm}$ 36561)

P. Maas et al. 5712 (Uw 27336)

de Haas and de Haas 441 (Uw 14447) 29 mm

H. van der Werff and van Hardeveld $23 \mathrm{~mm}$ 6825 (Uw 31172)

J. Cuatrecasas 17214 (Uw 25408)

K. L. Chambers 2648 (USw 33930)

B. Maguire and J. J. Wurdack 42076 (Tw 36495)

B. Maguire 24680 (Uw 2652)

J. C. Lindeman 5382 (Uw 3931)

S. Dressler s.n., 20.2.2004 (FR)

F. J. Breteler 3723 (Uw 11050)

S. Dressler s.n., 28.2.2004 (FR)

collector unknown (Tw 3836)

H. E. Desch 3750 (MADw 35871)

$60 \mathrm{~mm}$

mature

$18 \mathrm{~mm}$

$35 \mathrm{~mm}$

$42 \mathrm{~mm}$

$38 \mathrm{~mm}$

$15 \mathrm{~mm}$

$12 \mathrm{~mm}$

mature mature 


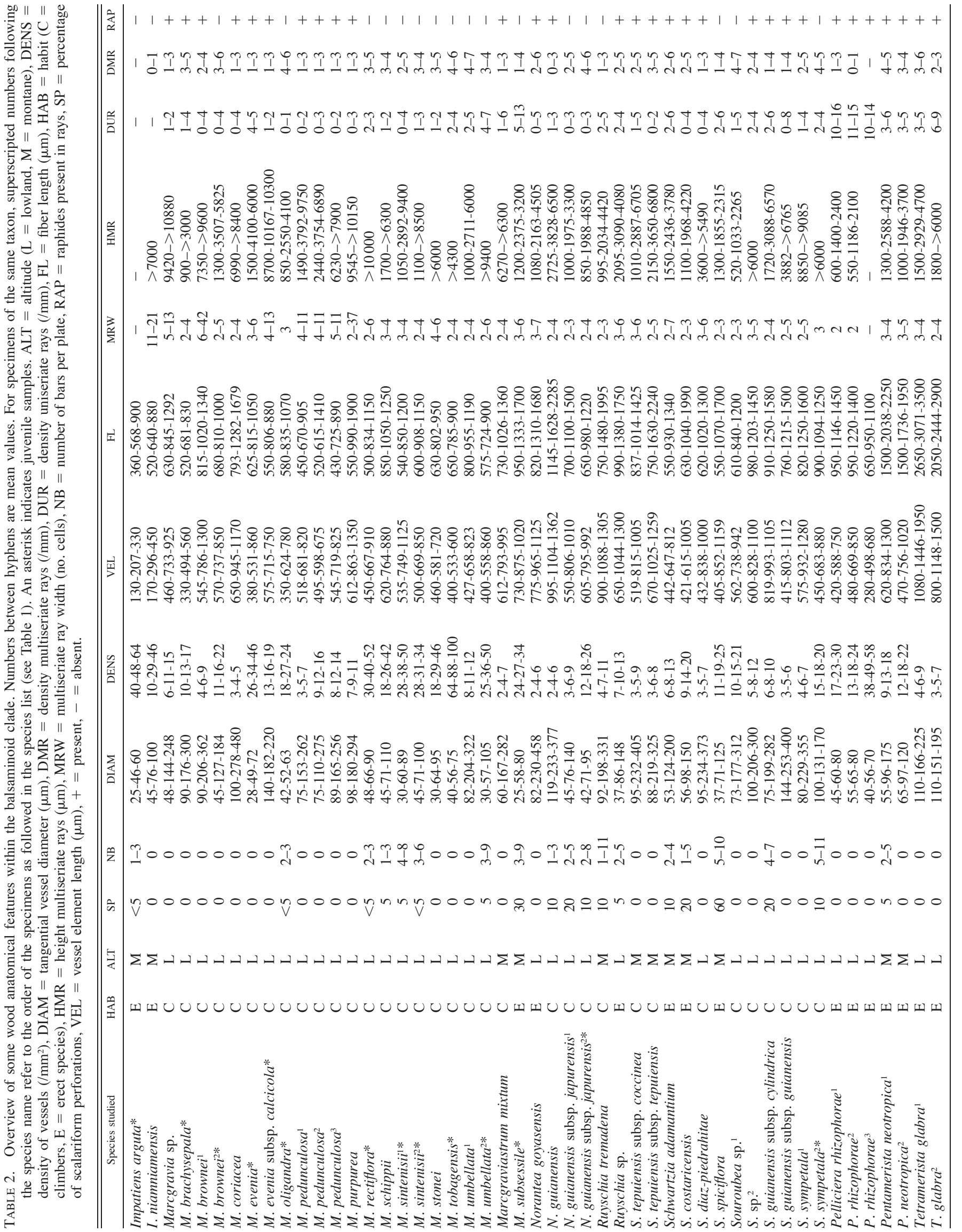



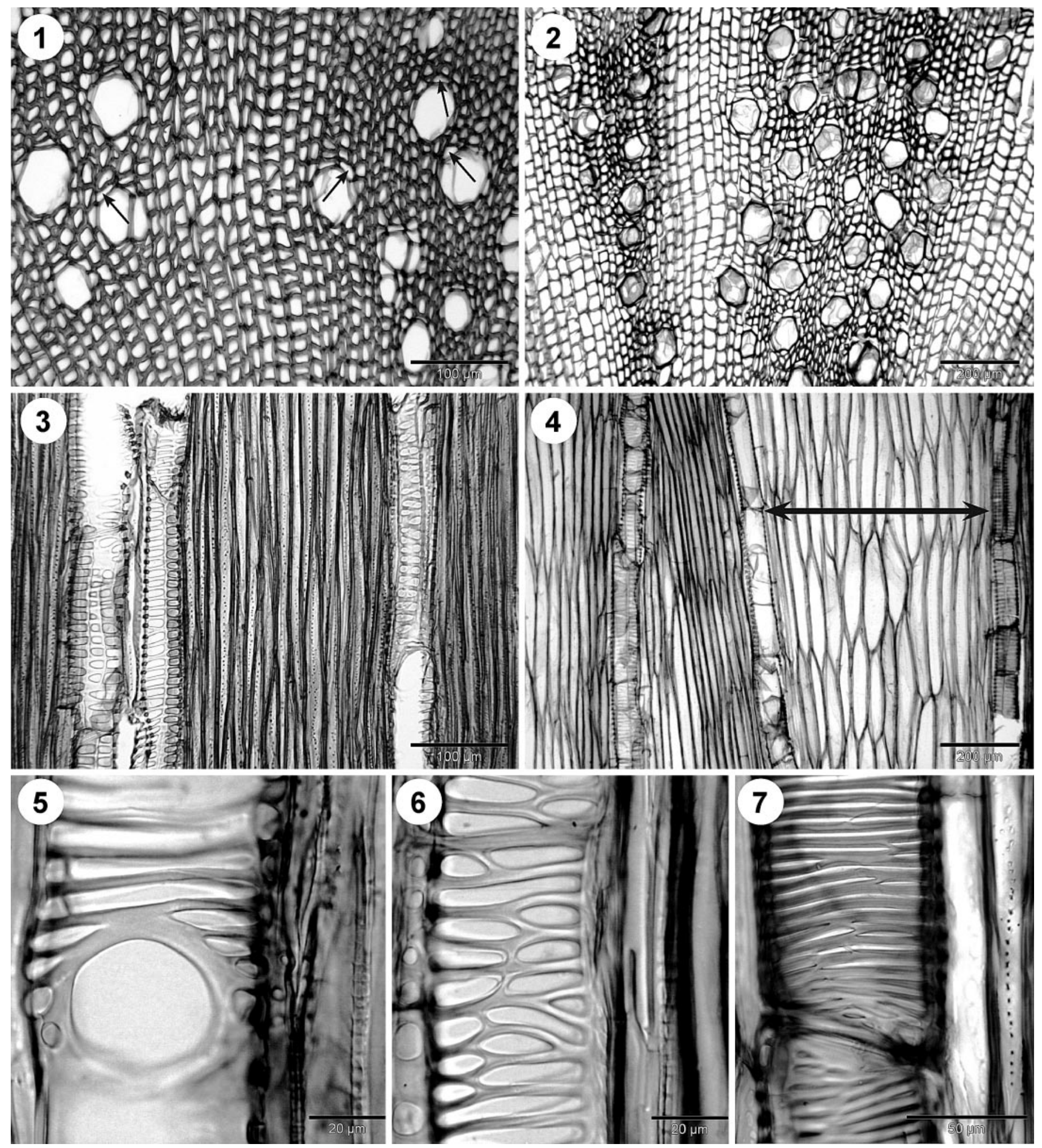

Figs. 1-7. Wood anatomical sections of Balsaminaceae (LM). 1. Impatiens arguta: transverse section (TS), vessels mainly solitary, scanty paratracheal parenchyma (arrows), radial band of wide thin-walled libriform fibers near the center of the image. 2. I. niamniamensis: TS, vessels mainly solitary, wide bands of rays alternating with zones including vessels, thin-walled fibers and parenchyma cells. 3. I. arguta: tangential longitudinal section (TLS), thin-walled fibers, scalariform vessel pitting, and lack of rays. 4. I. niamniamensis: TLS, storied thin-walled fibers (center), wide multiseriate ray with storied ray cells (arrow). 5 . I. arguta: radial longitudinal section (RLS), simple vessel perforation. 6. I. arguta: TLS, wide reticulate vessel pitting with strongly reduced borders. 7. I. niamniamensis: TLS, wide scalariform vessel pitting with reduced borders. 

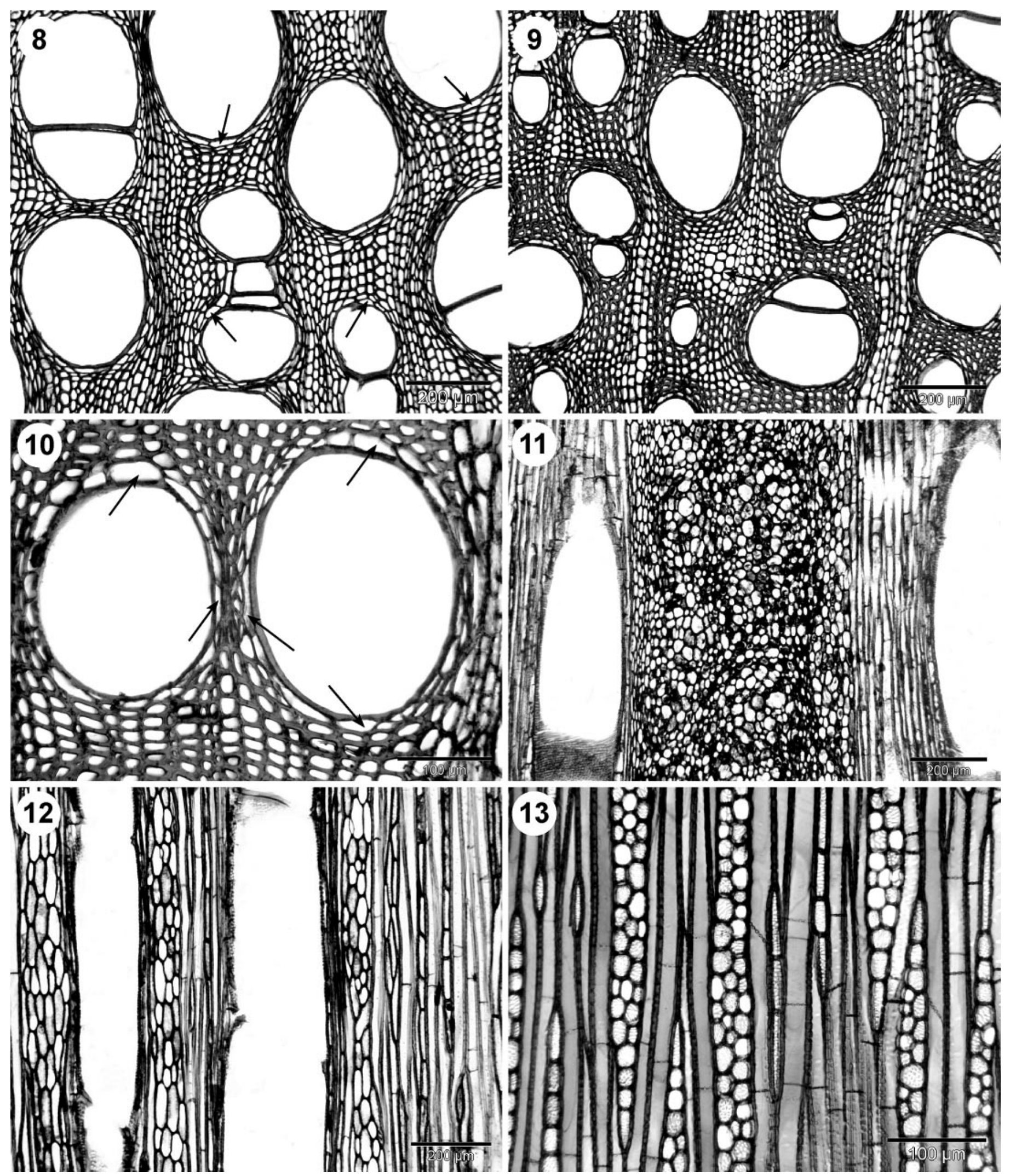

Figs. 8-13. Transverse and tangential longitudinal sections of Marcgraviaceae (LM). 8. Marcgraviastrum mixtum: TS, vessels solitary or in small radial multiples, scanty paratracheal parenchyma (arrows). 9. Marcgravia pedunculosa Uw 21928: TS, vessels, solitary or in small radial multiples, vasicentric paratracheal parenchyma, and apotracheal parenchyma in clusters (arrows). 10. M. pedunculosa Uw 21928: TS, detail of vessels with vasicentric paratracheal parenchyma (arrows). 11. M. purpurea: TLS, very wide multiseriate ray. 12. Sarcopera tepuiensis subsp. coccinea: TLS, relatively narrow, multiseriate rays. 13. Souroubea sp. Uw 3931: TLS, idem. 


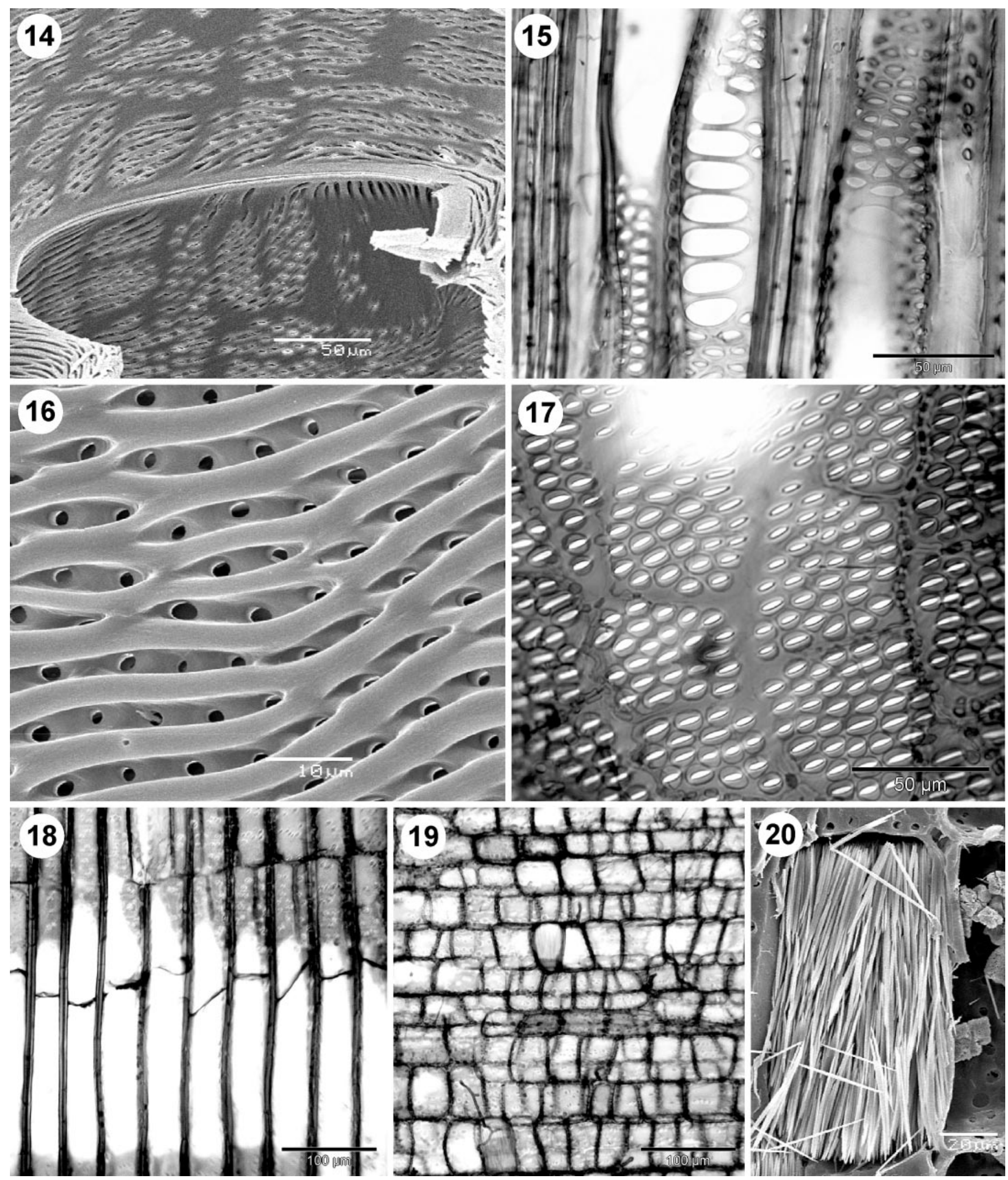

Figs. 14-20. Radial longitudinal surfaces (SEM) and sections (LM) of Marcgraviaceae. 14. Marcgravia umbellata Uw 15399: SEM, simple vessel perforation. 15. Schwartzia spiciflora: LM, scalariform vessel perforation. 16. M. umbellata Uw 15399: SEM, coalescent pits in the inner wall of a vessel element. 17. $M$. umbellata Uw 15399: LM, alternate vessel-ray pits. 18. Sarcopera tepuiensis subsp. coccinea: LM, septate libriform fibers. 19. Marcgravia sp.: LM, heterocellular multiseriate ray consisting of procumbent, square, and upright body ray cells. 20. Norantea goyasensis: SEM, raphides in upright ray cell. 
distinctly bordered, sometimes coalescent (Fig. 16), pits (3)6-10-(20) $\mu \mathrm{m}$ in horizontal diameter, non-vestured. Vesselray pits mostly alternate and comparable to intervessel pits in shape and size (Fig. 17), but sometimes scalariform and distinctly bordered, pits (15)-18-25-(45) $\mu \mathrm{m}$ in horizontal diameter. Tangential diameter of vessels (25)-50-280-(480) $\mu \mathrm{m}$, vessel elements (330)-490-1100-(1362) $\mu \mathrm{m}$ long. Tracheids absent. In Marcgravia and Norantea, septate fibers with indistinctly to distinctly bordered pits in tangential and radial walls common, pit density between $10-20$ pits per $100 \mu \mathrm{m}$ of fiber length in both walls, fibers thin-walled, (430)-6101630-(2285) $\mu \mathrm{m}$ long, pit borders (2)-3-4-(6) $\mu \mathrm{m}$ in diameter; in the five other genera studied, septate fibers with simple to minutely bordered pits concentrated in radial walls dominant (Fig. 18), pit density between 10 and 20 pits per $100 \mu \mathrm{m}$ of fiber length in radial walls and less than 5 pits per $100 \mu \mathrm{m}$ of fiber length in tangential walls, fibers thin-walled, (550)840-1630-(2240) $\mu \mathrm{m}$ long, pit borders $2-3 \mu \mathrm{m}$ in diameter. Axial parenchyma vasicentric forming a one- (at some places two-) layered sheath around the vessels (Fig. 10), sometimes also apotracheal forming clusters in all genera (Fig. 9) in 3-8 celled strands. Uniseriate rays always present (Figs. 12-13), (150)-300-860-(1510) $\mu \mathrm{m}$ high, consisting of upright cells, $0-13$ rays $/ \mathrm{mm}$. Multiseriate rays mostly $2-5$-seriate (Figs. $12-$ 13), but up to 42-seriate in Marcgravia (Fig. 11), (520)-1030$10170-(>11000) \mu \mathrm{m}$ high, $0-7$ rays $/ \mathrm{mm}$, heterocellular consisting mostly of square and upright body ray cells and less frequently procumbent body ray cells (Fig. 19), and two to more than four upright rows of marginal ray cells; sheath cells absent. Gummy deposits, probably tannins, in ray cells. Raphides predominantly present in upright ray cells of most species studied (see Table 2, Fig. 20).

Pellicieraceae (Pelliciera 1/1; Figs. 21-26) - Growth rings absent. Wood diffuse-porous. Vessels (13)-15-50-(58)/ $\mathrm{mm}^{2}$, sometimes solitary but usually in radial multiples of 2-9 (Figs. 21-22), exceptionally in clusters of 2-7 vessels (in MADw 17595), vessel outline slightly angular. Vessel perforation plates exclusively simple (Fig. 23). Intervessel pits alternate, distinctly bordered, pits 4-5 $\mu \mathrm{m}$ in horizontal diameter, nonvestured (Fig. 23). Vessel-ray pits similar to intervessel pits in shape and size, often unilaterally compound (Fig. 26). Helical sculpturing absent. Tangential diameter of vessels (40)-5565-(80) $\mu \mathrm{m}$, vessel elements (280)-500-670-(850) $\mu \mathrm{m}$ long. Tracheids absent. Fibers mostly septate, usually thin- to thickwalled, (650)-950-1220-(1450) $\mu \mathrm{m}$ long, with simple to minutely bordered pits concentrated in radial walls, pit borders 2-3 $\mu \mathrm{m}$ in diameter. Axial parenchyma scarce, diffuse apotracheal and scanty paratracheal (Fig. 22) in 2-3-celled strands. Uniseriate rays always present (Fig. 24), (550)-870-1300(2250) $\mu \mathrm{m}$ high, consisting of upright cells, 10-16 rays/mm. Multiseriate rays absent in Dressler s.n., but 2-(3)-seriate in MADw 17595 and Tw 39723 (Fig. 24), with long uniseriate tails, (550)-1190-1400-(2400) $\mu \mathrm{m}$ high, 0-2 rays $/ \mathrm{mm}$, consisting mainly of square to upright (and sometimes procumbent) body ray cells and more than four rows of upright marginal ray cells (Fig. 25); sheath cells absent. No gummy deposits observed. Raphides present in upright ray cells.

Tetrameristaceae (Pentamerista 1/1, Tetramerista 1/1-3; Figs. 27-32) - Growth ring boundaries absent. Wood diffuseporous. Vessels (9)-15-(22)/ $\mathrm{mm}^{2}$ in Pentamerista and (3)-5(9) $/ \mathrm{mm}^{2}$ in Tetramerista, sometimes solitary but more often in radial multiples of 2-4-(6) (Figs. 27-28), occasionally clustered in Pentamerista, vessel outline angular. Vessel perforations simple in Tetramerista, predominantly simple but sometimes scalariform in Pentamerista with 2-5 bars. Intervessel pits alternate, distinctly bordered, pits $4-6 \mu \mathrm{m}$ in horizontal diameter, non-vestured. Vessel-ray pits similar to intervessel pitting in shape and size, often unilaterally compound. Helical sculpturing absent. Tangential diameter of vessels (55)-100(175) $\mu \mathrm{m}$ in Pentamerista and (110)-150-170-(225) $\mu \mathrm{m}$ in Tetramerista, vessel elements (470)-760-830-(1300) $\mu \mathrm{m}$ long in Pentamerista and (800)-1150-1450-(1950) $\mu \mathrm{m}$ in Tetramerista. Tracheids absent. Fibers sometimes septate, very thick-walled, length (1500)-1740-2040-(2250) $\mu \mathrm{m}$ in Pentamerista and (2050)-2440-3070-(3500) $\mu \mathrm{m}$ in Tetramerista, with simple to minutely bordered pits concentrated in radial walls, pit borders $2-3 \mu \mathrm{m}$ in diameter. Axial parenchyma mainly diffuse to diffuse-in-aggregates but also scanty paratracheal (Figs. 27-28) in 4-9 celled strands. Uniseriate rays always present (Figs. 29-30), length (650)-1340-1880(3200) $\mu \mathrm{m}$ in Pentamerista and (650)-1570-2690-(8600) $\mu \mathrm{m}$ in Tetramerista, consisting of upright cells, 2-6 rays $/ \mathrm{mm}$. Multiseriate rays 2-5-seriate (Figs. 29-30), sometimes connected by long uniseriate tails, length (1000)-1950-2590(4200) $\mu \mathrm{m}$ in Pentamerista and (1500)-3500-(>6000) $\mu \mathrm{m}$ in Tetramerista, 2-6 rays $/ \mathrm{mm}$, consisting of procumbent and square body ray cells (Figs. 31-32) and more than four rows of upright marginal ray cells; sheath cells absent. Gummy deposits, possibly tannins, observed in Tetramerista. Raphides present in procumbent (Tetramerista) or procumbent and square ray cells (Pentamerista).

\section{DISCUSSION}

There are several disagreements between the descriptions given in this work and earlier studies, and this is especially the case for Marcgraviaceae. For example, Vestal (1937) and Metcalfe and Chalk (1950) mentioned that the wood structure of Norantea s.l. differs in many aspects from the wood of Marcgravia and Souroubea, but this is refuted in this study and in some previous studies (de Roon, 1975; Bedell, 1980). Furthermore, Bedell (1980) mentioned several features that could not be supported by us, i.e., vestured, opposite to transitional intervessel pits in Ruyschia, fibers with helical thickenings in Marcgravia, Norantea s.l., and Souroubea, predominantly homocellular rays consisting of mainly upright cells, and the presence of secretory canals in Schwartzia. This author also reported a lack of axial parenchyma in Ruyschia and Schwartzia and the absence of uniseriate rays in species of Marcgravia, Ruyschia, and Souroubea, two features that are present in all wood samples that we examined. According to our observations, at least some of these differences may be due to the juvenile nature of the wood. Indeed, some of our juvenile Marcgravia samples had very little axial parenchyma, almost no uniseriate rays, and multiseriate rays with exclusively upright ray cells. Previous wood anatomical descriptions of Tetrameristaceae and Pellicieraceae are similar to our results, although Bedell (1980) did not observe uniseriate rays in Tetramerista, a feature that was clearly observed by us.

Wood anatomical comparison of Marcgraviaceae, Pellicieraceae, and Tetrameristaceae-The close relationship of Marcgraviaceae, Pellicieraceae, and Tetrameristaceae is supported by several wood anatomical features, such as a high 

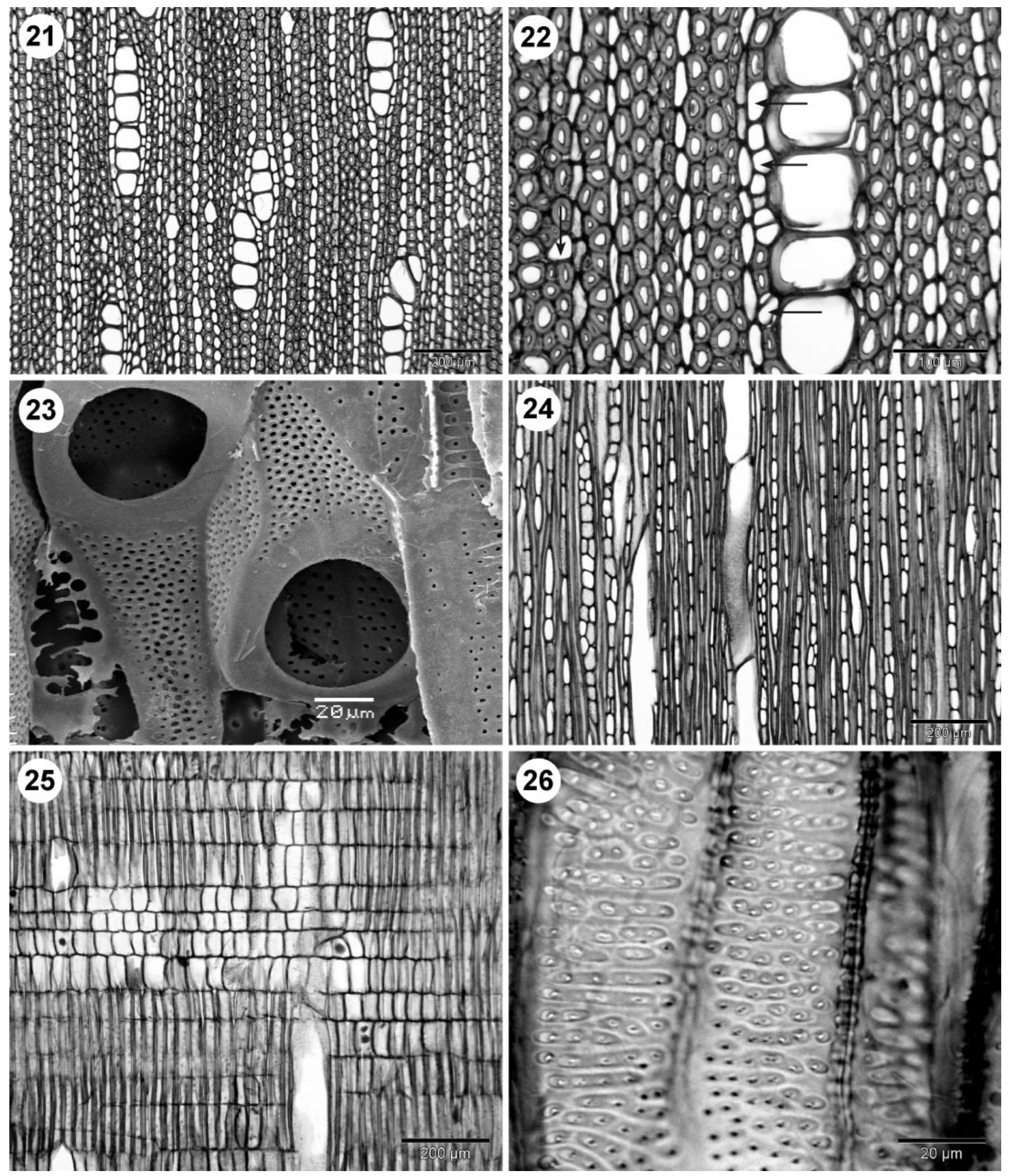

Figs. 21-26. Wood anatomical sections (LM; Figs. 21-22, 24-26) and a radial longitudinal surface (SEM; Fig. 23) of Pelliciera rhizophorae. 21. Tw 39723: LM, TS, vessels in long radial multiples. 22. MADw 17595: LM, TS, axial parenchyma scanty paratracheal (horizontal arrows) and diffuse apotracheal (vertical arrow). 23. Tw 39723: SEM, RLS, simple vessel perforations, alternate intervessel pits. 24. Tw 39723: LM, TLS, uniseriate and narrow multiseriate rays. 25. Tw 39723: LM, RLS, heterocellular, multiseriate ray consisting of square and upright cells. 26. Tw 39723: LM, RLS, unilaterally compound vessel-ray pits. 

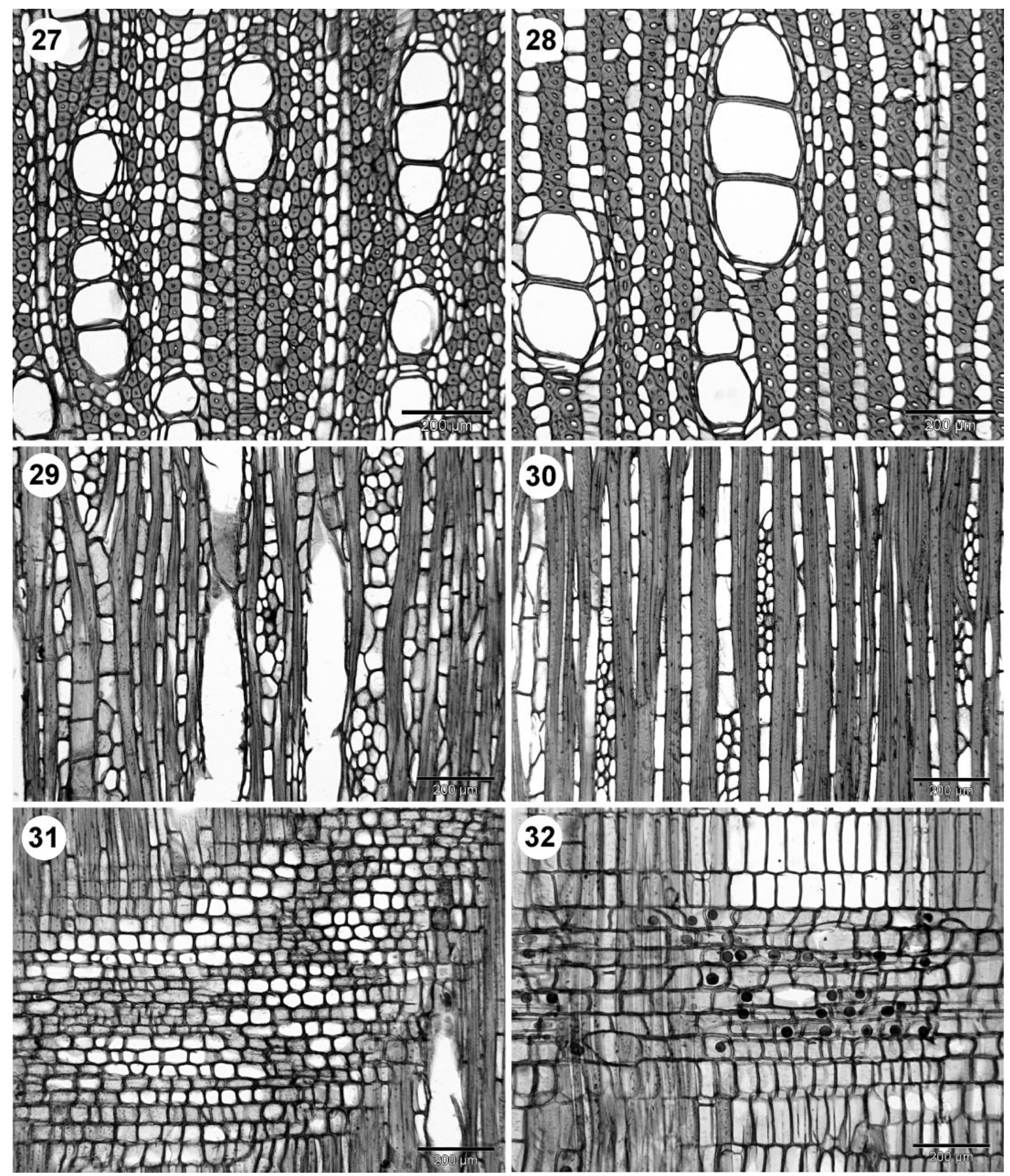

Figs. 27-32. Wood anatomical sections of Tetrameristaceae (LM). 27. Pentamerista neotropica MADw 23508: TS, vessels solitary or in radial multiples, very thick-walled fibers, axial parenchyma diffuse to diffuse-in-aggregates and scanty paratracheal 28. Tetramerista glabra MADw 35871: TS, idem. 29. Pentamerista neotropica MADw 23508: TLS, uniseriate and 3-4-seriate rays. 30. Tetramerista glabra MADw 35871: TLS, uniseriate and 2-3-seriate rays with long uniseriate parts. 31. Pentamerista neotropica MADw 23508: RLS, multiseriate ray consisting of procumbent and square body ray cells. 32. Tetramerista glabra MADw 35871: RLS, multiseriate ray with unknown inclusions (possibly tannins), consisting of procumbent and square body ray cells and upright marginal ray cells. 


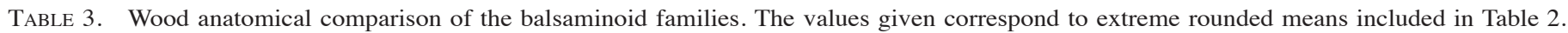
Numbers in parentheses occur sporadically. $+=$ present, $-=$ absent,$\pm=$ sometimes present.

\begin{tabular}{|c|c|c|c|c|}
\hline Character & Balsaminaceae & Marcgraviaceae & Pellicieraceae & Tetrameristaceae \\
\hline Secondary woodiness & + & - & - & - \\
\hline Scalariform perforations & - & \pm & - & \pm \\
\hline Radial vessel multiples (no. cells) & $(2-3)$ & $2-4-(7)$ & $2-9$ & $2-4-(6)$ \\
\hline Vessel diameter $(\mu \mathrm{m})$ & $40-80$ & $50-280$ & $55-65$ & $100-170$ \\
\hline Vessel element length $(\mu \mathrm{m})$ & $210-300$ & $490-1100$ & $500-670$ & $1150-1450$ \\
\hline Unilaterally compound vessel-ray pitting & - & - & + & + \\
\hline Mean fiber length $(\mu \mathrm{m})$ & $570-640$ & $610-1630$ & $950-1220$ & $1740-3070$ \\
\hline Very thick-walled fibers & - & - & \pm & + \\
\hline Axial parenchyma diffuse-in-aggregates & - & - & - & + \\
\hline Axial parenchyma vasicentric & \pm & + & - & - \\
\hline Mean multiseriate ray width (no. cells) & - or $10-20$ & $2-15-(42)$ & $2-(3)$ & $2-5$ \\
\hline Mean multiseriate ray height $(\mathrm{mm})$ & - or $>7$ & $1-10$ & $1.1-1.4$ & $2.0-3.5$ \\
\hline Multiseriate rays with long uniseriate ends & - & - & + & + \\
\hline Raphides & + & + & + & + \\
\hline
\end{tabular}

frequency of radial vessel multiples, predominantly simple vessel perforation plates, alternate intervascular pitting, a mixed occurrence of apotracheal and paratracheal parenchyma, predominantly septate libriform fibers, co-occurrence of uniseriate and multiseriate rays, and raphides in ray cells (see also Beauvisage, 1920; Baretta-Kuipers, 1976; Bedell, 1980). Most of these characters are also observed in the unrelated woody primuloids, but the presence of raphides in rays is typical of balsaminoids. In addition, two other features that clearly distinguishes woody balsaminoids from primuloids is the general absence of uniseriate rays in Myrsinaceae and Theophrastaceae, and the lack of apotracheal parenchyma in primuloids (Lens et al., 2005).

Despite the anatomical resemblances mentioned, the wood structure allows us to distinguish the three balsaminoid families from each other (Table 3 ). Tetrameristaceae are defined by exclusively, very thick-walled fibers and diffuse-in-aggregates axial parenchyma, two features that are normally absent in Pellicieraceae and Marcgraviaceae. The low percentage of septate fibers within Tetrameristaceae could be underestimated because of the very thick fiber walls that complicate the observation of septa. Furthermore, the genus Tetramerista is characterized by the presence of raphides in procumbent ray cells and by the occurrence of very long fibers, often between 2500 and $3000 \mu \mathrm{m}$. Long fibers are not unusual in Ericales; they are also found in Lecythidaceae s.l. (Carlquist, 1988), Symplocaceae (van den Oever, 1981), and Theaceae (Liang and Baas, 1990). Pellicieraceae are defined by long radial vessel multiples of up to nine cells, sparse axial parenchyma (diffuse apotracheal and scanty paratracheal), and narrow multiseriate rays. Typical features of Marcgraviaceae include vasicentric parenchyma, multiseriate rays including upright, square, and procumbent body ray cells, and multiseriate rays with few rows of marginal ray cells. In addition, the presence of very wide vessels (more than $250 \mu \mathrm{m}$ ), which are always rounded in outline, and wide (more than five-seriate) and high multiseriate rays (more than $10 \mathrm{~mm}$ ) are diagnostic of Marcgraviaceae wood.

From a wood anatomical point of view, it is obvious that Pentamerista and Tetramerista are closely related. The differences in quantitative features, such as the narrower and shorter vessel elements and shorter fibers in Pentamerista, are probably related to their habit (shrub vs. tree). The placement of Pelliciera within Tetrameristaceae seems justified because of the presence of unilaterally compound vessel-ray pits and long uniseriate ends of multiseriate rays interconnecting multiseriate parts, two features that are absent in other balsaminoid representatives (see also Baretta-Kuipers, 1976; Bedell, 1980). However, the wood of Pelliciera rhizophorae can be clearly distinguished from Tetrameristaceae by the presence of narrow multiseriate rays. Besides this, Pelliciera shows a significantly lower vessel diameter and vessel element length and a higher vessel density. The difference in vessel diameter and vessel density in Pelliciera can be explained by the high xylem tensions in mangrove trees due to the physiological dry (saline) environment. Indeed, the mangrove environment often results in a high number of narrow vessels, which increase the safety of the sap stream (Tomlinson, 1986). The shorter vessel elements in Pelliciera might have the same effect (Carlquist, 1977), although Panshin (1932) and van Vliet (1976) noticed that the vessel element length of mangrove species does not differ significantly from inland representatives in various families. In conclusion, we think that it is justified to accept the enlarged family concept of Tetrameristaceae with inclusion of Pelliciera, as has already been proposed by Bremer et al. (2002) and APG II (2003).

Phylogenetic and ecological wood anatomy of Marcgraviaceae-The wood structure of Marcgraviaceae shows various features that are typical of lianas, such as wide vessel elements in co-occurrence with narrow vessels (vessel dimorphism), simple vessel perforations, paratracheal parenchyma and interspersed apotracheal parenchyma, and wide rays (Carlquist, 1989). However, true tracheids or vasicentric tracheids, which are also common in lianas, were not observed. Although Marcgraviaceae are wood anatomically homogeneous, there is considerable variation in the width of the multiseriate rays. Mature wood of Marcgravia is often characterized by wide multiseriate rays (usually 5-15-seriate, sometimes up to 42seriate), while most species of Noranteoideae have narrower (2-5-seriate) multiseriate rays. This difference remains when Marcgravia species, which grow exclusively as lianas, are compared with the other scandent species that characteristically show a more self-supporting, scrambling habit (on average nine-seriate vs. three-seriate, respectively). Therefore, the difference in multiseriate ray width caused by dissimilar growth strategies is phylogenetically important within the family, and it may represent an additional feature to distinguish Marcgravioideae from Noranteoideae, besides other features such as the specific umbellate inflorescence, the tetramery in 


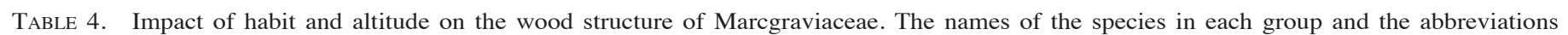
are given in Table 2. Numbers are mean values followed by standard deviations. An asterisk indicates that the values are statistically different at the $0.5 \%$ level. $\mathrm{N}=$ number of specimens.

\begin{tabular}{|c|c|c|c|c|c|c|c|c|c|}
\hline Species studied & $\mathrm{N}$ & SP & NB & DIAM & DENS & VEL & FL & MRW & HMR \\
\hline Lowland climbers & 16 & $3 \pm 6$ & $1 \pm 1$ & $195 \pm 65$ & $9 \pm 6$ & $810 \pm 139$ & $1040 \pm 255$ & $7 \pm 6$ & $6330 \pm 3285$ \\
\hline Montane climbers & 4 & $3 \pm 5$ & $1 \pm 1$ & $205^{*} \pm 28$ & $6 \pm 1$ & $930 \pm 148$ & $1290 \pm 315$ & $3 \pm 1$ & $3990 \pm 2708$ \\
\hline Lowland erect species & 2 & $5 \pm 7$ & $2 \pm 2$ & $160 \pm 102$ & $7 \pm 4$ & $1005 \pm 56$ & $1345 \pm 50$ & $4 \pm 0$ & $2630 \pm 656$ \\
\hline Erect montane species & 3 & $35 \pm 25$ & $4 \pm 2$ & $100 * \pm 27$ & $14 \pm 6$ & $705 \pm 129$ & $1010 \pm 73$ & $4 \pm 1$ & $2090 \pm 308$ \\
\hline
\end{tabular}

the perianth, and the occurrence of leaf dimorphism in Marcgravia (Dressler, 2004). Other ericalean taxa with very wide rays (more than 20-seriate) include the unrelated epacrids (Ericaceae) and primuloids (Theophrastaceae and Myrsinaceae), although lianas are mostly absent in these groups (Lens et al., 2003, 2005).

As mentioned in previous studies, altitudinal ranges may influence the wood structure, although altitudinal trends are less pronounced than latitudinal trends (Van der Graaff and Baas, 1974; van den Oever et al., 1981; Baas, 1986b; Carlquist, 2001; Lens et al., 2004). Within Marcgraviaceae, the most manifest differences between the 16 species representing lowland climbers and the four montane climbing species are the multiseriate ray width (seven-seriate vs. three-seriate, respectively) and height (6330 vs. $3990 \mu \mathrm{m}$, respectively) (Table $4)$. The two erect species from the lowlands differ from the three montane erect species in having a lower percentage of scalariform perforations (5\% vs. 35\%, respectively), larger vessel diameters (160 vs. $100 \mathrm{~m}$, respectively), a lower vessel density ( 7 vs. 14, respectively), longer vessel elements (1005 vs. $705 \mu \mathrm{m}$, respectively) and fibers (1345 vs. $1010 \mu \mathrm{m}$, respectively), and higher multiseriate rays (2630 vs. $2090 \mu \mathrm{m}$, respectively). These trends are in agreement with general altitudinal trends reported by the above authors, although none of these trends are significant at the $0.5 \%$ level.

Likewise, there are clear signals of the impact of habit on various wood anatomical features in Marcgraviaceae (Table 4), and they corroborate most correlations found in previous studies (Baas and Schweingruber, 1987; Carlquist, 2001; Lens et al., 2004). The mean vessel diameter between climbers and erect species from the montane regions demonstrates the clearest habit trend in our analysis because the values are statistically significant at the $0.5 \%$ level (205 vs. $100 \mu \mathrm{m}$, respectively; Table 4). Several other trends can be mentioned, such as the higher percentage of scalariform perforations and a higher vessel density in montane erect species compared to montane climbers. Furthermore, climbing species from both lowland and montane regions have higher multiseriate rays than their erect counterparts (Table 4). The data on perforation types explain why scalariform perforations are more common in the Norantea s.l. complex because of the abundant occurrence of montane shrubs and treelets among this group (Vestal, 1937; Metcalfe and Chalk, 1950). The impact of habit on the vessel element and fiber lengths is somewhat contradicting (see also Carlquist, 1989). Indeed, montane climbers have longer vessel elements and fibers than montane erect species, but lowland climbers show shorter mean vessel elements and fibers than lowland erect species.

Secondary woodiness in Balsaminaceae-From a wood anatomical point of view, the systematic position of Balsaminaceae is difficult to compare with other balsaminoid members because of the secondary woodiness of this family. Indeed, the few Impatiens species with a limited production of secondary xylem are scattered throughout the molecular tree of Yuan et al. (2004), indicating that this phenomenon has evolved multiple times from herbaceous ancestors. Two features that provide wood anatomical evidence for the occurrence of secondary woodiness are the raylessness in I. arguta and the presence of exclusively upright ray cells in I. niamniamensis (Carlquist, 1992). Furthermore, the wood anatomical search for close relatives of Balsaminaceae is complicated more because of additional paedomorphic features, a term indicating that primitive features from the primary xylem are transferred into the secondary xylem (Carlquist, 1962). The most important evidence for paedomorphism within the two species studied is the gradual decrease of vessel element length from the center of the stem towards the cambium. Indeed, vessel elements in the primary xylem are clearly longer $(280-330 \mu \mathrm{m}$ in I. arguta, 380-450 $\mu \mathrm{m}$ in I. niamniamensis) than vessel elements that are situated near the cambium (130-170 $\mu \mathrm{m}$ in I. arguta, 170$220 \mu \mathrm{m}$ in I. niamniamensis). Other paedomorphic features include wide scalariform to reticulate vessel pits, and thinwalled libriform fibers that are relatively wide. Furthermore, I. niamniamensis shows abundant axial parenchyma and wide and high rays, two features that are common in paedomorphic woods (Carlquist, 1962).

As seen in tangential sections of I. niamniamensis, the shape and size of the ray cells corresponds fairly well with the libriform fibers (Fig. 4). In I. arguta, the difference between ray cells and libriform fibers is vague, resulting in raylessness. This is in agreement with the hypothesis of Carlquist (1970) stating that the increase of xylem production in woody herbs with very short fusiform cambium initials may lead to libriform fibers that are histologically equivalent to ray cells.

Our observations of I. niamniamensis resemble the wood of I. lyallii, which also shows a high percentage of parenchyma tissue (Gerard, 1917). Nevertheless, major differences in $I$. lyallii are the presence of narrow (1-2-seriate) and low (200$300 \mu \mathrm{m})$ rays, and extremely short fibers $(150-250 \mu \mathrm{m})$. Because raphides are occasionally observed in the wood of $I$. niamniamensis, this character remains the only anatomicalmorphological link between Balsaminaceae and the other three balsaminoid families. Besides this observation, Balsaminaceae characteristically show raphides within special cells of the leaves, cortex, and in the anther walls (Cronquist, 1988; Fischer, 2004).

\section{LITERATURE CITED}

Anderberg, A. A., C. Rydin, And M. Källersjö. 2002. Phylogenetic relationships in the order Ericales s.1.: analyses of molecular data from five genes from the plastid and mitochondrial genomes. American Journal of Botany 89: 677-687.

APG II. 2003. An update of the Angiosperm Phylogeny Group classification 
for the orders and families of flowering plants: APG II. Botanical Journal of the Linnean Society 141: 399-436.

BAAS, P. 1986a. Terminology of imperforate tracheary elements-in defence of libriform fibres with minutely bordered pits. International Association of Wood Anatomists Bulletin, new series 7: 82-86.

BAAS, P. 1986b. Ecological patterns in xylem wood anatomy. In T. J. Givnish [ed.], On the economy of plant form and function, 327-352. Cambridge University Press, Cambridge, UK.

BAAS, P., AND F. SCHWEINGRUBER. 1987. Ecological trends in the wood anatomy of trees, shrubs and climbers from Europe. International Association of Wood Anatomists Bulletin, new series 8: 245-274.

BARETTA-KuiPERS, T. 1976. Comparative wood anatomy of Bonnetiaceae, Theaceae and Guttiferae. Leiden Botanical Series 3: 76-101.

Beauvisage, L. 1920. Contribution à l'étude anatomique de la famille des Ternstroemiacées. E. Arrault, Tours, France.

Bedell, H. G. 1980. Comparative anatomy and systematics of Marcgraviaceae, Pellicieraceae, and Tetrameristaceae (Theales). Master thesis, University of Maryland, College Park, Maryland, USA.

Bremer, B., K. Bremer, N. Heidari, P. Erixon, R. G. Olmstead, A. A. ANDERberG, M. KällersJö, AND E. BARKhordarian. 2002. Phylogenetics of asterids based on 3 coding and 3 non-coding chloroplast DNA markers and the utility of non-coding DNA at higher taxonomic levels. Molecular Phylogenetics and Evolution 24: 274-301.

Brummit, R. K., AND C. E. Powell. 1992. Authors of plant names. Royal Botanic Gardens, Kew, UK.

CARlquist, S. 1962. A theory of paedomorphosis in dicotyledonous woods. Phytomorphology 12: 30-45.

CARLQUIST, S. 1970. Wood anatomy of insular species of Plantago and the problem of raylessness. Bulletin of the Torrey Botanical Club 97: 353-361.

CARlquist, S. 1977. Wood anatomy of Onagraceae: additional species and concepts. Annals of the Missouri Botanical Garden 64: 627-637.

CArlquist, S. 1988. Wood anatomy of Scytopetalaceae. Aliso 12: 63-76.

CARLQUIST, S. 1989. Anatomy of vine and liana stems: a review and synthesis. In F. E. Putz and H. A. Mooney [eds.], The biology of vines, 5371. Cambridge University Press, Cambridge, UK.

CARlquist, S. 1992. Wood anatomy of sympetalous dicotyledon families: a summary, with comments on systematic relationships and evolution of the woody habit. Annals of the Missouri Botanical Garden 79: 303-332.

CARlquist, S. 2001. Comparative wood anatomy. Systematic, ecological, and evolutionary aspects of dicotyledon wood, 2nd ed. Springer-Verlag, Berlin, Germany.

CRONQUist, A. 1988. The evolution and classification of flowering plants, 2nd ed. New York Botanical Garden, New York, New York, USA.

DAHLGREN, G. 1989. An updated angiosperm classification. Botanical Journal of the Linnean Society 100: 197-203.

DE Roon, A. C. 1975. Contributions towards a monograph of the Marcgraviaceae. Ph.D. thesis, University of Utrecht, Utrecht, Netherlands.

DE Roon, A. C., AND S. Dressler. 1997. New taxa of Norantea Aubl. s.1. (Marcgraviaceae) from Central America and adjacent South America. Botanische Jahrbücher für Systematik 119: 327-335.

Dressler, S. 1994. Marcgravia L. (Marcgraviaceae) in der Karibik-Studien zur Evolution und Systematik der Gattung. Ph.D. thesis, Humboldt University, Berlin, Germany.

DressLer, S. 2004. Marcgraviaceae. In K. Kubitzki [ed.], Families and genera of vascular plants, vol. 6, 258-265. Springer-Verlag, Berlin, Germany.

FISCHER, E. 2004. Balsaminaceae. In K. Kubitzki [ed.], Families and genera of vascular plants, vol. 6, 20-25. Springer-Verlag, Berlin, Germany.

FrankLIN, G. L. 1945. Preparation of thin sections of synthetic resins and wood-resin composites, and a new maceration method for wood. Nature 155: 51 .

Gerard, A. M. 1917. Recherches sur la spécification histologique de différents bois de Madagascar, avec étude comparative des principaux bois industriels d'Europe. Lons-Le-Saunier, Paris, France.

Geuten, K., E. Smets, P. Schols, Y.-M. Yuan, S. Janssens, P. KüPfer, AND N. PYCK. 2004. Conflicting phylogenies of balsaminoid families and the polytomy in Ericales: combining data in a Bayesian framework. Molecular Phylogenetics and Evolution 31: 711-729.

GreY-Wilson, C. 1980. Hybridisation in African Impatiens. Studies in Balsaminaceae. Kew Bulletin 34: 689-722.

HAllieR, H. 1916. Beiträge zur Flora von Borneo. Marcgraviaceae. Beihefte zum Botanischen Centralblatt 34, II. Abt.: 35-40.
HALlieR, H. 1921. Beiträge zur Kenntnis der Linaceae (DC. 1819) Dumort. Beihefte zum Botanischen Centralblatt 39, II. Abt.: 1-178.

Holmgren, P. K., N. H. Holmgren, and L. C. Barnett. 1990. Index herbariorum, part I, The herbaria of the world, 8th ed. Regnum Vegetabile 120: $1-693$.

IAWA CоммітTEE. 1989. IAWA list of microscopic features for hardwood identification. International Association of Wood Anatomists Bulletin, new series 10: 219-332.

Juel, H. O. 1887. Beiträge zur Anatomie der Marcgraviaceen. Bihang till Kongliga Svenska Vetenskapsacademiens Handlingar 12, afd. 3, nr. 5: $1-28$.

KobUski, C. E. 1951. Studies in the Theaceae, XXIII. The genus Pelliciera. Journal of the Arnold Arboretum 32: 256-262.

Lens, F., P. Gasson, E. Smets, And S. Jansen. 2003. Comparative wood anatomy of epacrids (Styphelioideae, Ericaceae s.1.). Annals of Botany 91: 835-856.

Lens, F., J. L. Luteyn, E. Smets, And S. Jansen. 2004. Ecological trends in the wood anatomy of Vaccinioideae (Ericaceae s.1.). Flora 199: 309319.

Lens, F., S. JAnsen, P. Caris, L. Serlet, and E. Smets. 2005. Comparative wood anatomy of the primuloid families. Systematic Botany 30: 162 182.

LIANG, D., AND P. BAAS. 1990. Wood anatomy of trees and shrubs from China. II. Theaceae. International Association of Wood Anatomists Bulletin, new series 11: 337-378.

Maguire, B., C. De Zeeuw, Y.-C. Huang, and C. C. Clare JR. 1972. Tetrameristaceae. In B. Maguire [ed.], The botany of the Guayana Highland, part IX. Memoirs of the New York Botanical Garden 23: 165-192.

Metcalfe, C. R., AND L. Chalk. 1950. Anatomy of the dicotyledons, 1st ed., vol. 2. Clarendon Press, Oxford, UK.

Panshin, A. J. 1932. An anatomical study of the woods of the Philippine mangrove swamps. Philippine Journal of Science 48: 143-207.

RECORD, S. J. 1942. American woods of the family Theaceae. Tropical Woods 70: 23-33.

ReCoRD, S. J., AND R. W. HeSs. 1943. Timbers of the New World. Yale University Press, New Haven, Connecticut, USA.

Roth, L. C., AND A. GRIJALVA. 1991. New record of the mangrove Pelliciera rhizophorae (Theaceae) on the Caribbean coast of Nicaragua. Rhodora 93: $183-186$.

Savolainen, V., M. W. Chase, S. B. Hoot, C. M. Morton, D. E. Soltis, C. B. BAYER, M. F. FAY, A. Y. DE BRUiJn, S. Sullivan, AND Y.-L. QUi. 2000. Phylogenetics of flowering plants based on combined analyses of plastid $a t p B$ and $r b c L$ gene sequences. Systematic Botany 49: 306-362.

SolTis, D. E., ET AL. 2000. Angiosperm phylogeny inferred from $18 \mathrm{~S}$ rDNA, $r b c L$, and $a t p B$ sequences. Botanical Journal of the Linnean Society 133: 381-461.

STERN, W. L. 1988. Index xylariorum. Institutional wood collections of the world, 3rd ed. International Association of Wood Anatomists Bulletin, new series 9: 204-252.

TAKHTAJAN, A. 1997. Diversity and classification of flowering plants. Cambridge University Press, New York, New York, USA.

THorne, R. F. 2000. The classification and geography of the flowering plants: dicotyledons of the class angiospermae: (subclasses Magnoliidae, Ranunculidae, Caryophyllidae, Dilleniidae, Rosidae, Asteridae, and Lamiidae). Botanical Review 66: 441-647.

Tomlinson, P. B. 1986. The botany of mangroves. Cambridge University Press, New York, New York, USA.

van Den Oever, L., P. BaAs, AND M. Zandee. 1981. Comparative wood anatomy of Symplocos and latitude and altitude of provenance. International Association of Wood Anatomists Bulletin, new series 2: 3-24.

VAN DER GRAAFF, N. A., AND P. BAAs. 1974. Wood anatomical variation in relation to latitude and altitude. Blumea 22: 101-121.

van Vliet, G. J. C. M. 1976. Wood anatomy of Rhizophoraceae. Leiden Botanical Series 3: 20-75.

Vestal, P. A. 1937. The significance of comparative wood anatomy in establishing the relationship of the Hypericaceae to the Guttiferae and their allies. Philippine Journal of Science 64: 199-256.

WARD, M. N., AND R. A. PRICE. 2002. Phylogenetic relationships of Marcgraviaceae: insights from three chloroplast genes. Systematic Botany 27: $149-160$.

WiLLiams, L. 1936. Woods of northeastern Peru. Marcgraviaceae. Field Museum of Natural History, Botanical Series 15: 334-335.

Yuan, Y.-M., Y. Song, K. Geuten, E. Rahelivololona, S. Wohlhauser, E. FISCHER, E. SMETS, AND P. KÜPFER. 2004. Phylogeny and biogeography of Balsaminaceae inferred from ITS sequence data. Taxon 53: 391-404. 